\title{
STEP-BY-STEP ESOPHAGOJEJUNAL ANASTOMOSIS AFTER INTRA- CORPOREAL TOTAL GASTRECTOMY FOR LAPAROSCOPIC GASTRIC CANCER TREATMENT: TECHNIQUE OF "REVERSE ANVIL"
}

\author{
Passo a passo da anastomose esofagojejunal intra-corpórea após gastrectomia total para o tratamento do câncer \\ gástrico por laparoscopia: padronização técnica da "ogiva reversa"
}

Croider Franco LACERDA, Paulo Anderson BERTULUCCI, Antônio Talvane Torres de OLIVEIRA

From the Departamento de Cirurgia Oncológica do Aparelho Digestivo Alto, Hospital de Câncer de Barretos (Department of Oncologic Surgery for High Digestive System, Barretos Hospital), Barretos, SP, Brazil.

HEADINGS - Reconstruction by laparoscopy. Esophagojejunal anastomosis. Reverse anvil. Gastrectomy. Gastric cancer.
ABSTRACT - Background: The laparoscopic gastrectomy is a relatively new procedure due mainly to the difficulties related to lymphadenectomy and reconstruction. Until the moment, technique or device to perform the esophagojejunal anastomosis by laparoscopy is still a challenge. So, a safe, cheap and quickly performing technique is desirable to be developed. Aim: To present technique proposed by the authors with its technical details on reconstruction with "reverse anvil". Method: After total gastrectomy completed intra-corporeally, the reconstruction starts with the preparation of the intraabdominal esophagus cross-section next to the esophagogastric transition of $50 \%$. A graduated device is prepared using Levine gastric tubes ( $n^{\circ} .14$ and 10), $3 \mathrm{~cm}$ length, connected to the anvil of the circular stapler ( $\left.n^{\circ} .25\right)$ with a wire thread (2-0 or 3-0) of $10 \mathrm{~cm}$, which is connected to end of this device. The whole device is introduced in reverse esophagus. The esophagus is amputated and the wire is pulled after previous transfixation in the distal esophagus and the anvil positioned. The jejunal loop is sectioned $20-30 \mathrm{~cm}$ from duodenojejunal angle, and the anvil put in the jejunal loop and connect previously in the esophagus. Linear stapler (blue $60 \mathrm{~mm}$ ) is used to close the opening of the jejunal loop. Conclusion: The "reverse anvil" technique used by the authors facilitated the transit reestablishment after total gastrectomy, contributing to obviate reconstruction problems after total gastrectomy.

\section{Correspondence: \\ Croider Franco Lacerda \\ croider@hotmail.com}

Financial source: none

Conflicts of interest: none

Received for publication: 18/10/2013

Accepted for publication: 05/12/2013
RESUMO - Racional: A gastrectomia laparoscópica é relativamente recente em função da dificuldade técnica relacionada à linfadenectomia e reconstrução. Até o momento, não se tem uma técnica ou dispositivo para realizar a anastomose esofagojejunal por laparoscopia que seja segura, de baixo custo e rápida execução. Objetivo: Apresentar técnica proposta pelos autores com seus detalhes técnicos de reconstrução com "ogiva reversa". Método: Após gastrectomia total completamente intra-corpórea, a reconstrução inicia-se com o preparo do esôfago intra-abdominal, com secção transversal de $50 \%$, próximo a transição esofagogástrica. O dispositivo é preparado usando as sondas de Levine ( $n^{\circ} .14$ e 10), com $3 \mathrm{~cm}$ de comprimento, ligado à ogiva do grampeador circular $\left(n^{\circ} .25\right)$ e um fio agulhado (2-0 ou 3-0) de $10 \mathrm{~cm}$, ligado ao final do dispositivo que é introduzido no sentido inverso ao esôfago; ele é amputado e o fio puxado em seguida, posicionando a ogiva no esôfago distal. O jejuno a 20-30 cm do ângulo duodenojejunal é seccionado, introduzindo-se o grampeador no jejuno e conectando-o à ogiva, previamente posicionada no esôfago. Grampeador linear (azul de $60 \mathrm{~mm}$ ) é utilizado para fechar a abertura do "cajado" do jejuno. Conclusão: A técnica de "ogiva reversa" utilizada pelos autores, facilitou a reconstrução do trânsito digestivo, contribuindo para diminuir as dificuldades técnicas na sua reconstrução após gastrectomia total.
DESCRTORES - Reconstrução por laparoscopia. Anastomose esofagojejunal. Ogiva reversa. Gastrectomia. Cancer gástrico.

\section{INTRODUCTION}

$\mathrm{T}$ he official history of laparoscopic gastric resection begins in Singapore in 1992, when Goh et al. ${ }^{5}$, performed the first distal gastrectomy with Billroth II reconstruction, in an elderly patient, carrier of chronic gastric ulcer. The first reconstruction laparoscopic gastrectomy Billroth II for the treatment of cancer was performed by Kitano et al. ${ }^{9}$, in 1992 and published in 1994. In Belgium, in June 1993, Azagra et al. ${ }^{1,2}$, performed the 
first total gastrectomy for treatment of gastric cancer and in 1999, published his experience with 13 patients, concluding that laparoscopy for treatment of gastric cancer is feasible, oncologically safe and should be used for patients with early lesions, reserving the combined surgery (video-assisted) to more advanced lesions. In 2006, this author also participated in a multicenter study, in which were analyzed 130 patients with gastric adenocarcinoma, followed by 49 months on average, and concluded that the laparoscopic gastrectomy with any type of lymphadenectomy and even as a palliative method is a safe procedure, with acceptable mortality rates in patients with advanced gastric cancer, usually in unfavorable clinical conditions, and that laparoscopy for localized disease, is equivalent to open surgery with the same oncological outcomes and the advantages already mentioned for laparoscopy ${ }^{7}$. Kitano et al. ${ }^{10}$, in 2007, published a multicenter study in Japan for early gastric cancer, indicating that laparoscopic surgery is associated with less time of hospital stay, least postoperative pain, better cosmetic outcome and disease-free survival at five years similar to open surgery for stages I and II.

Seventeen years later of the first laparoscopic resection for gastric cancer, Japanese society of gastric cancer, included in its guidance in 2010 laparoscopic surgery for cancers in stages $1 \mathrm{~A}$ and $1 \mathrm{~B}^{15}$. A metaanalysis published by Kodera et al. ${ }^{11}$, in 2010, with the aim of trying to answer the the existing controversies, which concluded that laparoscopic surgery with D2 lymphadenectomy is feasible, safe, complies with the oncologic principles and should be performed at centers with amount, training and experience are adequate to perform the procedure ${ }^{4}$. However, there were no significant differences in the morbidity, mortality, and oncological safety in several randomized trials related to early gastric cancer ${ }^{11,17,18}$. The experience in the west is small, because of the few cases of early gastric cancer with little previously published series about advanced gastric cancer $3,6,14,19$.

Thus, over the years of laparoscopic surgery, several reconstruction techniques of esophagojejunal anastomosis were cited such as: video-assisted techniques, anastomose side-by-side with linear stapler, circular stapler with the anvil placed transorally, among many others ${ }^{18,12,13,16}$. Despite several techniques are available for esophagojejunal anastomosis, does not exist a technique for laparoscopic surgery intracorporeal, that is really effective, reproducible, low cost which is rapidly performed.

\section{TECHNIC}

\section{Position of trocars}

The surgical steps of initial total gastrectomy and D2 lymphadenectomy are similar, following the same technical standards of the conventional approach (open surgery). The positioning of the patient is in lithotomy position with lower limbs extended, removed and properly supported in the leggings proper, the surgeon is positioned between the legs and the assistant surgeon (camera-man) on his left side of the patient. The monitor, when single is positioned to the right side of the surgical table next to his shoulder of the patient. Six trocars are used in the procedure as shown in Figure 1.

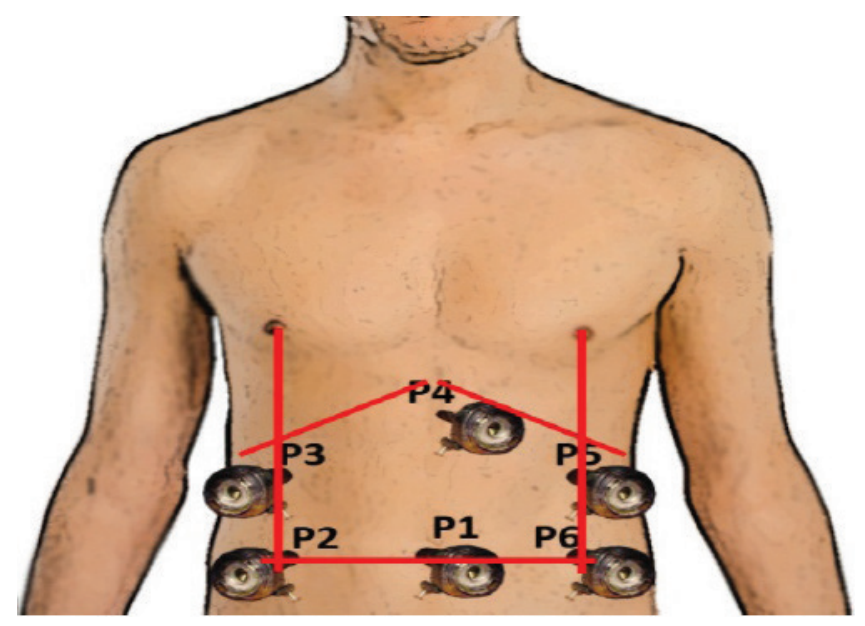

FIGURE 1 - Position of the trocars at a total gastrectomy, in the format of a "home": P1 - 11 mm trocar in the umbilical scar (optical $10 \mathrm{~mm}$ and 30 degrees); P2 and P3 - 12 mm trocars in the left and right flanks; P5 and P6 - In line passing through the right and left nipple; P4 - $5 \mathrm{~mm}$ trocars in the position xiphoid (retractor)

Dissection of gastro-esophageal junction and preparation of esophago-jejunal anastomosis.

After resection of the stomach and D2 lymphadenectomy, the operation continue to prepare of the esophagus for reconstruction of the interstinal Roux-Y fashion. Dissection is carried on towards the hiatal area and the phrenoesophageal membrane is further dissected. This preparation begins with the dissection of the surrounding tissue towards the esophageal hiatus, flush to the right branch of the diaphragmatic crus and ligament gastrophrenic releasing the esophagus in $360^{\circ}$, with the $2^{\text {nd }}$ assistant pulling the esophagus anteriorly and inferiorly, including the lymph node chain 1 and lymph node chain 3. A tape is placed around the gastroesophageal junction. It is tied in order to close the lumen of the gastroesophageal junction and to prevent any potential fluid dissemination from the stomach.

Preparing to position the anvil preferably $25 \mathrm{~mm}$ The surgeon (P2) repairs the esophagus with a small ribbon or yarn using in his hand a trocar for laparoscopic grasper (P6) and apprehends its end so that the assistant surgeon pull the 
distal portion of esophagus and also occlude the opening in the stomach. The surgeon apprehends the tape with a laparoscopic grasper or with the needle holders using the trocar (P6). Thereafter, the anesthesiologist aspires the secretions contained in the esophagus using a Levine nasogastric tube, removed it. Thereafter, the esophagus is sectioned only in the front face at the distal position from its left to right across to the esophagus until sectioning approximately $50 \%$ of the diameter the esophagus (Figure 2). Special attention must be outlet during esophageal section, in cases where the tumors located near the esophagogastric junction.

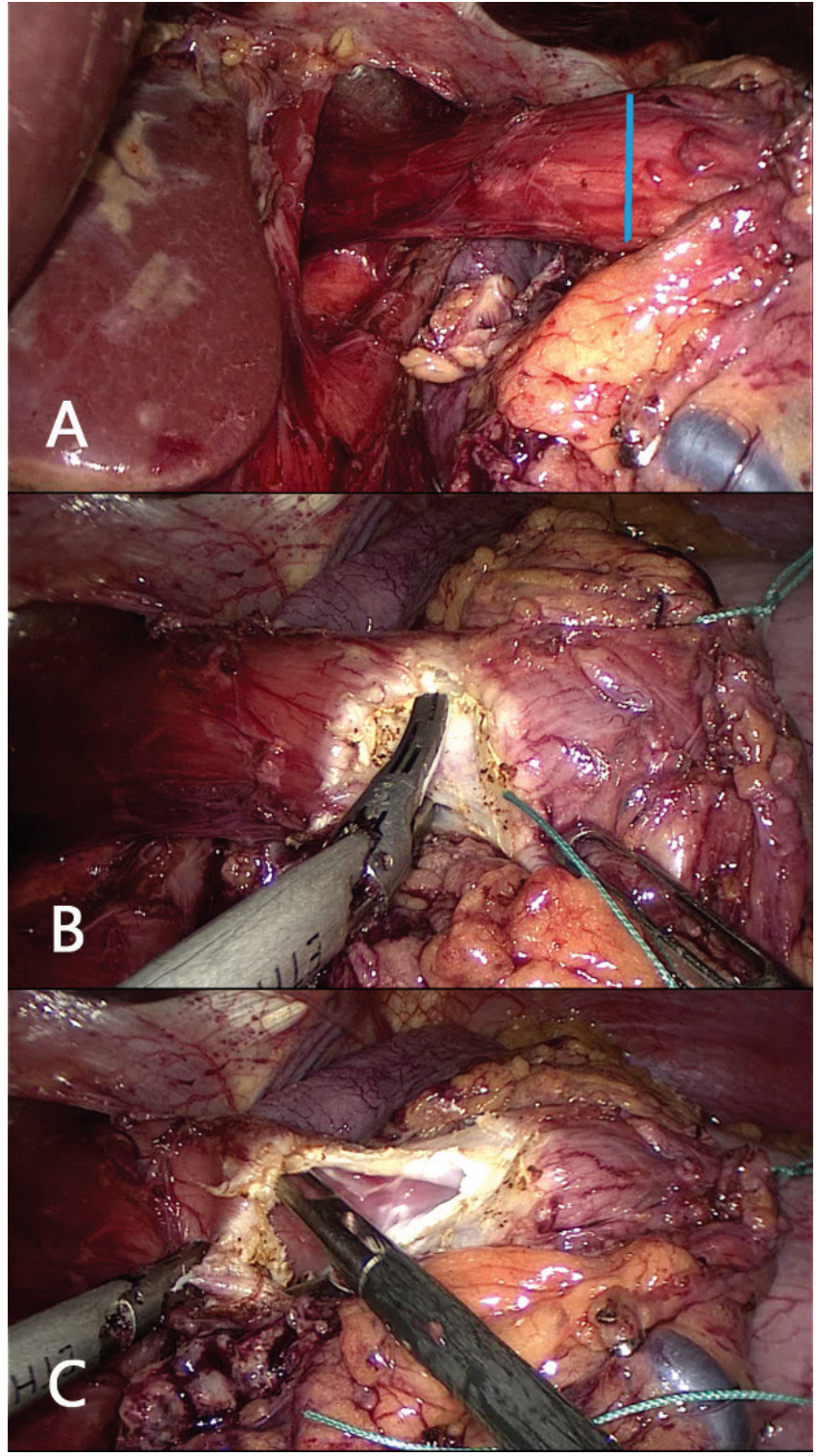

FIGURE 2 - A) Preparation of the esophagus to the opening on the right front lateral (marked in blue in the figure above); B) opening is performed device with Harmonic Ace ${ }^{\circledR}$ (Ethicon); C) opening in the esophagus through which will be introduced the anvil of the circular stapler number 25
Introduction of the anvil of the circular stapler

The procedure follows with the magnification of the portal (P6), this magnification should be large enough for the passage of the anvil of the circular stapler $25 \mathrm{~mm}$ down into the abdominal cavity. But first the anvil of the circular stapler must be prepared according to the description in Figure 3.

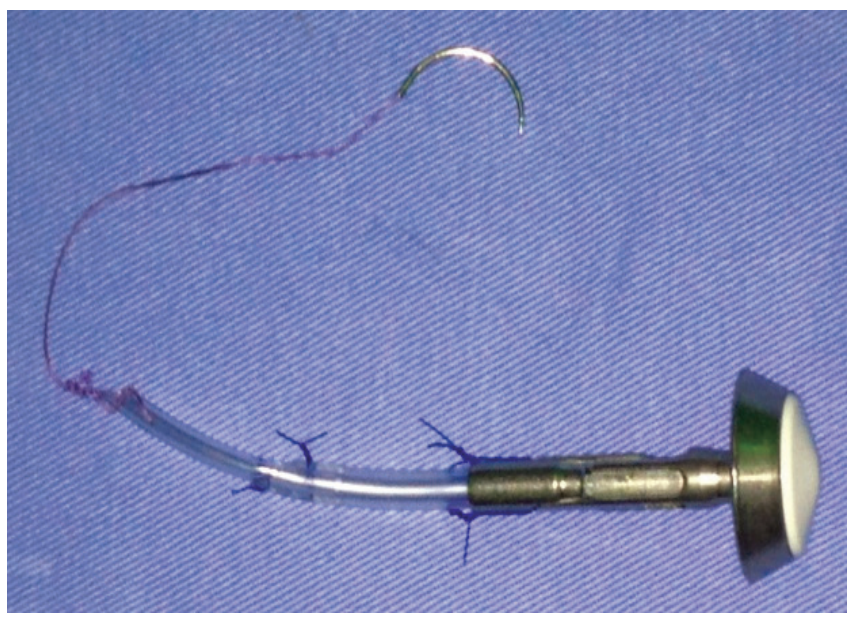

FIGURE 3 - The device of "reverse anvil"

The device is prepared using an anvil of the circular stapler, preferably of number 25; a small Levine gastric tube, length of $3 \mathrm{~cm}$ and number 14, is connected to the anvil fixed with Prolene (3-0). Thereafter another Levine tube (number 10) is introduced inside the number 14 tube and fixed with Prolene (3-0). Then, the tip is fixed at the end of Levine tube (number 10) with Vicryl for 10 to $15 \mathrm{~cm}$ with a 2.5 needle.

This done, the anvil is introduced into the cavity and is again introduced into trocar incision (P6) and this trocar is fixed with the assistance of forceps Backaus, so that there is no leak of gas (pneumoperitoneum). To introduce the anvil inside the esophagus, the surgeon uses the forceps in the portal (P6), grasps the proximal edge lateral of the esophagus transected by $\mathrm{P} 2$ applying traction it in order to expose the inside of the esophagus, while the $1^{\text {st }}$ assistant apprehends the distal portion of the esophagus, applying traction laterally in the opposite direction of the surgeon. The anvil is introduced for about 4 to $5 \mathrm{~cm}$ of the esophagus, then the surgeon through the trocar (P6) inserting the needle through the wall of the esophagus at the anterior portion of the opening of the body, 1 to $1.5 \mathrm{~cm}$ from the edge section, location in which the anvil is then exteriorized. The next step, the opening of the esophagus is closed with a linear stapler blue color of $60 \mathrm{~mm}$. Care must be taken to not reach the stapling line.

After checking the proper positioning of the anvil and thread, the surgeon through P3 introduces the $60 \mathrm{~mm}$ blue linear stapler, which is applied to the esophagus. P6 should pull laterally on the left while the 
$1^{\text {st }}$ assistant exerts traction in the opposite direction, using tape to pull this distal portion of the esophagus. The proximal esophagus should be completely closed. Section of the piece is completed, which will be extracted (distal esophagus, stomach, omentum and lymphadenectomy). The piece is sectioned, taken to the right upper quadrant just below the liver (Figure 4).

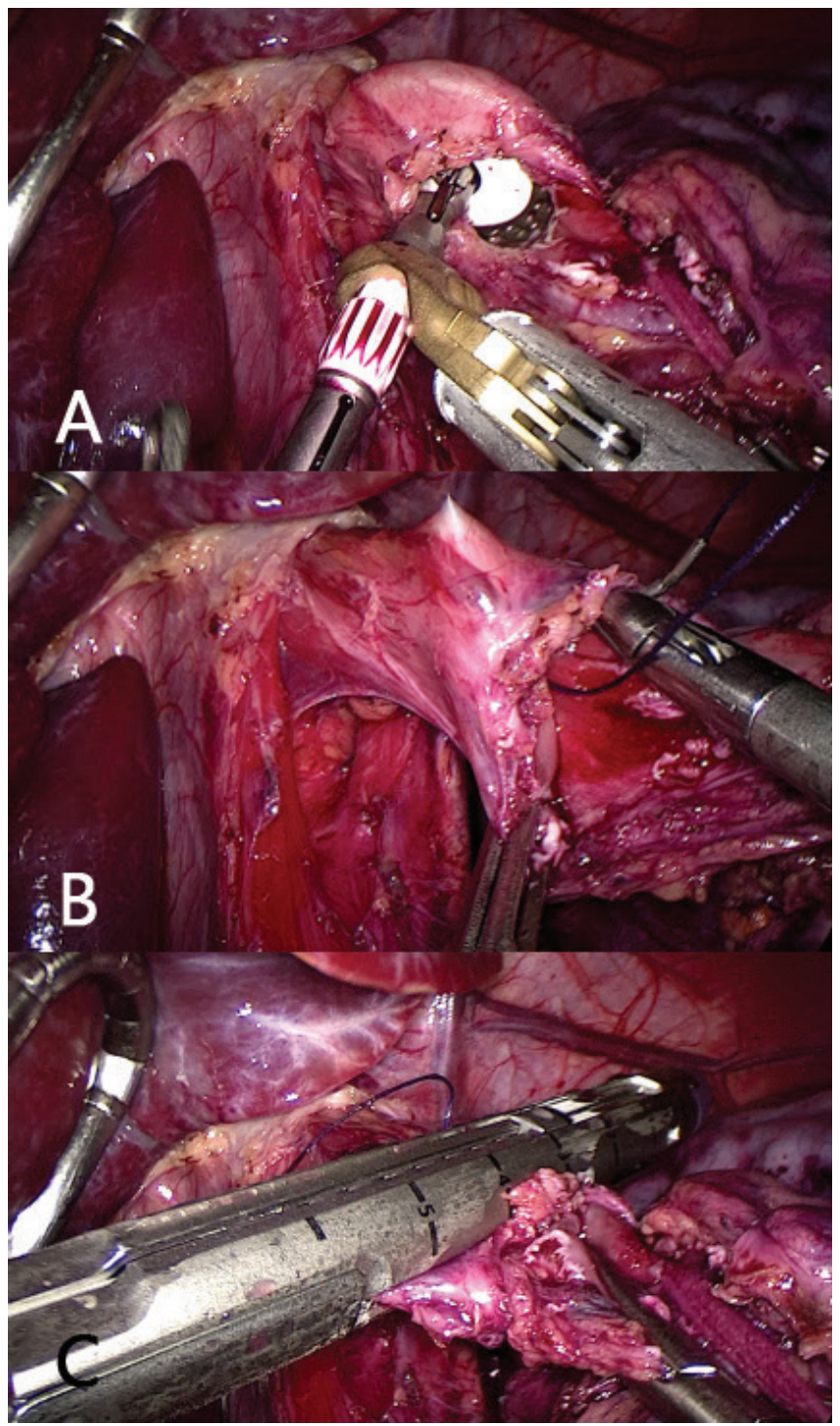

FIGURE 4 - A) Introduction of the anvil through the opening of the esophagus; B) introduction of the needle in the anterior wall of the esophagus, approximately $1.5 \mathrm{~cm}$ above the opening; C) amputation of the esophagus, taking care not cut the thread previously the passage using a laparoscopic linear stapler $60 \mathrm{~mm}$, preferably using blue or purple load.

\section{Pull the anvil}

The surgeon then by P2 and P6 preferentially uses two needle holder to pull the thread, so it can be externalized carefully. The $2^{\text {nd }}$ assist in P3, gently keeps the esophagus positioned, also assisted the $1^{\text {st }}$ assistant in P5. Gentle circular motions can be useful. After the complete positioning of the anvil the probes attached to it are removed. In that moment saline cleaning from all over the left upper quadrant, with the aspirator (P5) is done. Lymphadenectomy chains $11 p, 11 d$ and eventually the lymph node number 10 , in this moment can be easily performed by the exposure. This could be facilitated by the $1^{\text {st }}$ assistant tractioning the tissue superiorly through P5. The surgeon exerts traction on P2 and performs a lymph node dissection for P6.

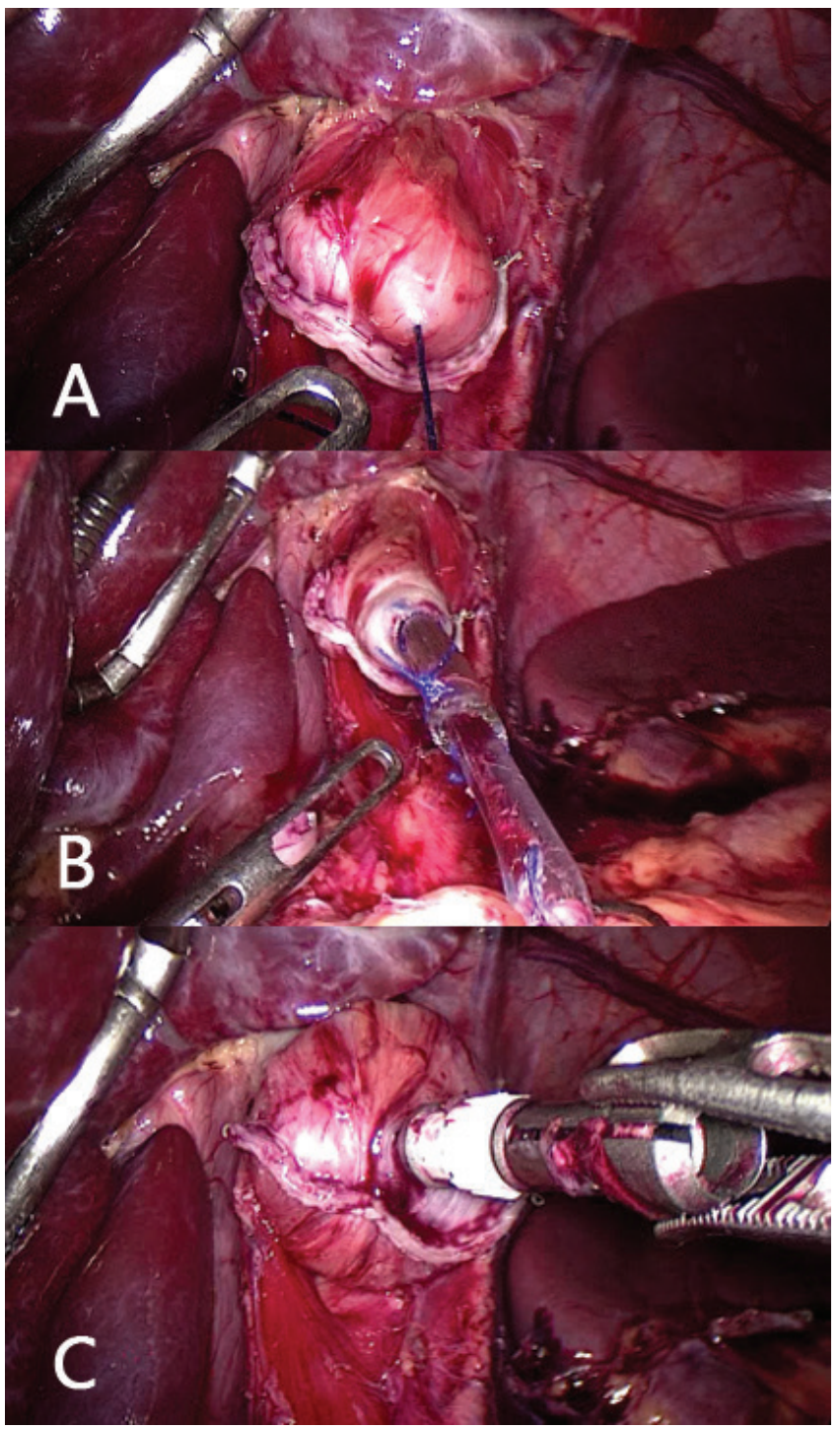

FIGURE 5 - A) Pull the thread gently; B) gastric tubes (Levine probes) now being pulled; C) positioning of the anvil in the distal esophagus

Opening of the mesocolon and section of the jejunum (transmesocolic technique)

The $1^{\text {st }}$ assistant picks up the transverse colon in its portion on the left and pulls antero-superiorly in order to present the mesocolon to the surgeon who picks up into its medium portion, laterally the middle colic vessels through $\mathrm{P} 2$, and $\mathrm{P} 6$ starts its openning with the ultrasonic forceps creating a continuity solution that allows the passage of the loop of 
jejunum to be anastomosed to the esophagus. The $2^{\text {nd }}$ assistant P3 picks up the colon or mesocolon and keeps it in traction. The $1^{\text {st }}$ assistant uses the trocar (P5) to aid the surgeon in loops exposure to the duodenojejunal angle and points section site of the jejunal loop, usually $25-30 \mathrm{~cm}$ from the angle. The surgeon (P2) takes the loop of the jejunum near the site of section and exerts traction laterally to his left while the $1^{\text {st }}$ assistant P5 grasps the same loop about $5 \mathrm{~cm}$ from the position of the surgeon, applying traction to it laterally toward the spleen. The surgeon (P6) promotes the opening of the mesentery and small intestine near the loop so as to allow the passage of the linear stapler $(60 \mathrm{~mm}$ blue color). The surgeon then places the stapler using the portal (P6), inserting the stem into the hole made thinner in the mesentery sure that the loop is located entirely between the stent and that no other structure is between them, proceeding with stapling and the loop section. Then the loop is passed through the opening of the mesocolon. The surgeon (P2) takes left opening of the mesocolon, the $1^{\text {st }}$ assistant P5 grasps the end on right of the opening and the surgeon P6 grasps the distal end the loop sectioned leading through the opening of mesocolon, moving, and then P2 and P5 catch the colon applying traction to it caudally so exposing the jejunal loop that will be anastomosed to the esophagus. The surgeon and the $1^{\text {st }}$ assistant position the jejunal loop, directed on the left in the patient.

\section{The esophagojejunal anastomosis}

The $1^{\text {st }}$ assistant P5 grasps the end of the stapling site; the surgeon P2 grasps the loop to about $3 \mathrm{~cm}$ from its end pulling in the opposite direction to the $1^{\text {st }}$ assistant; and P6 with the ultrasonic forceps promotes about 50\% loop opening. At this time the $2^{\text {nd }}$ assistant takes control of the camera and the $1^{\text {st }}$ removes cannula P6 through which introduces the circular stapler 21-25 mm according to the size of the loops and uses the Backaus to minimize the loss of gas around the stapler. The $1^{\text {st }}$ assistant in P5 grasps the lateral end of the opened loop, the surgeon P2 grasps the medial end the loop applying traction in the opposite direction to the $1^{\text {st }}$ assistant; $2^{\text {nd }}$ assistant P3 grasps the loop about 5-6 cm from its end and pulls it toward the diaphragm. The $1^{\text {st }}$ then enters the circular stapler (number 25) in the o jejunal opening about $5 \mathrm{~cm}$, keeping the whole (circular stapler and jejunal loop) stable. The $2^{\text {nd }}$ assistant $\mathrm{P} 3$ grasps the loop about 3-4 cm from the edge of the circular stapler and pulls it in the direction the pelvis, while keeping the loop tractioned to puncture the jejunal loop with the stapler, which will be connected to the anvil. The surgeon grasps the anvil with the appropriate grasper to docking with the stapler. The proximal and distal small bowel are kept under tension gently until there is a complete stapling. The stapler is removed again and the trocar is again positioned in P6, repositioned with the aid of Backaus. The loop stump is closed; for that, $1^{\text {st }}$ assistant P5 grasps the lateral end of the stump and surgeon P2 takes its medial part exposing the mesentery that can be dissected P6 to close the aperture with the use of a linear stapler ( $60 \mathrm{~mm}$ blue) towards from its mesenteric to anti-mesenteric border. The specimen can be removed through P6 (Figure 6).

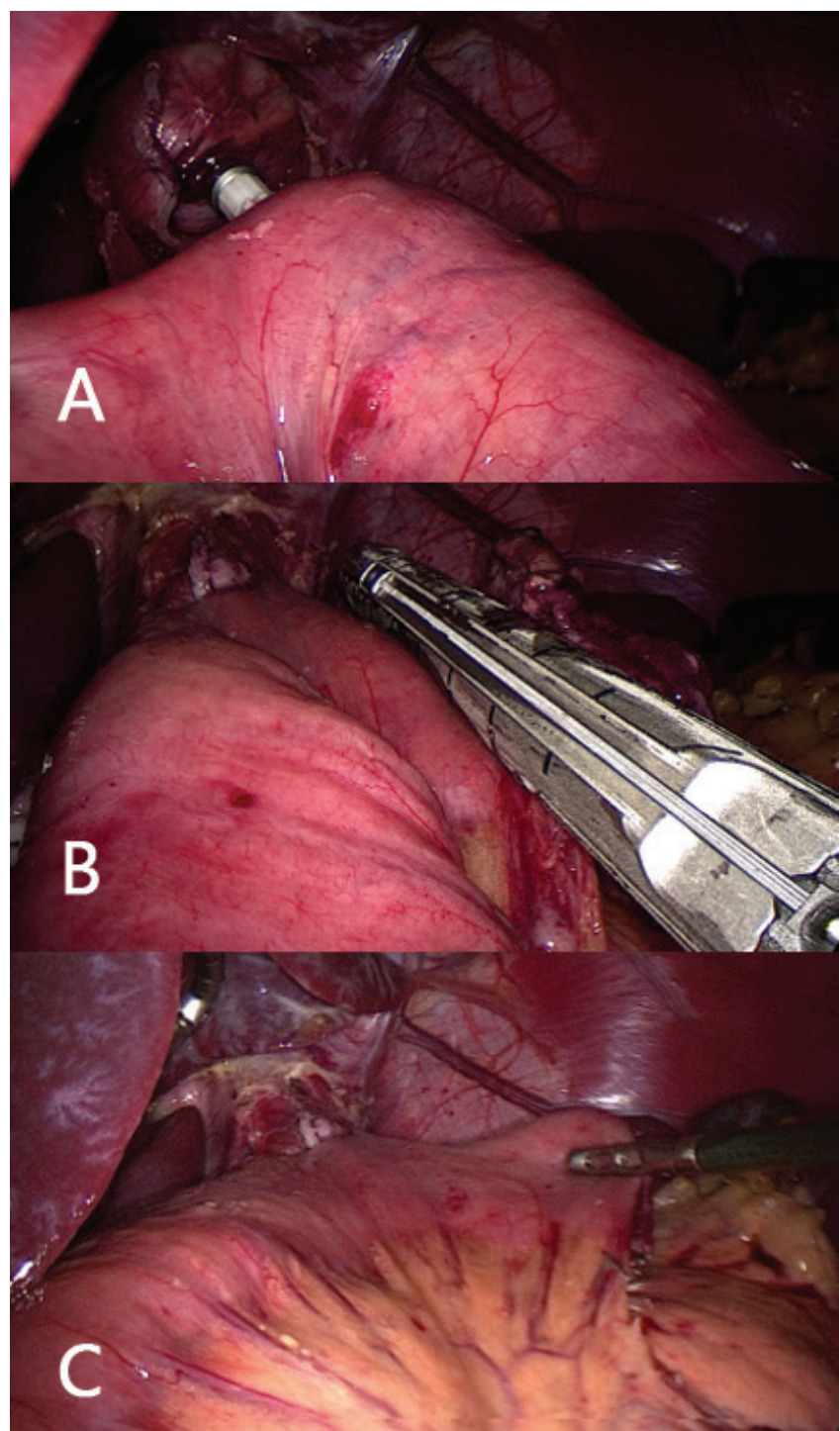

FIGURE 6 - A) Connection of the circular stapler already inserted into the opening of the jejunal loop and connected to the anvil for posterior stapling; B) use of a laparoscopic linear stapler (blue $60 \mathrm{~mm}$ ) for synthesis of the opening of the jejunal loop, through which it is introduced the circular stapler (number 25); C) final result of the esophageal-jejunal anastomosis.

\section{Jejuno-jejunal anastomosis}

The surgeons $\mathrm{P} 2$ and $\mathrm{P} 6$ follows until the desired distance - on average $30 \mathrm{~cm}$ from the esophagealjejunal anastomosis - and delivery to the $2^{\text {nd }}$ assistant P3 to maintain its exposure close to the abdominal 
wall. Then, the surgeon (P2) identifies the jejunum (bileo-pancreatic limb) grasps near its end. In P6 the surgeon grasps the jejunum about 4 to $5 \mathrm{~cm}$ from the point where $\mathrm{P} 3$ grasps are and presents the $1^{\text {st }}$ assistant through P5 with a dissector connected to the monopolar cable performing the cauterization and opening of the handle on its anti-mesenteric edge for the passage of the stapler. The same procedure is performed on the bileo-pancreatic limb. The P3 and P2 presentations are maintained by the surgeon that introduces the stapler in P6, and P5 for 1st assistant that with atraumatic grasper help the surgeon to introduce the linear stapler (white or blue $45 \mathrm{~mm}$ ) on the holes of jejunal loops. The loops are adjusted till they are symmetrical and touching each other on theirs anti-mesenteric edges; then, stapling is performed. The stapler is retrieved by the $1^{\text {st }}$ assistant grasps near the region of the anastomosis and presents it to the surgeon to opening the device. The surgeon through the portal (P2) can use a grasper and introduces the needle holder with PDS II 3-0 to perform the closure of the opening by continuous suture into two lines. Only extra-mucosal closing can also be practiced. The test with methylene blue or patent blue is not performed, and the same is done with the nasogastric tube to feed the patient.

Gas is closed and the portal P6 is removed. The incision is amplified in about $5 \mathrm{~cm}$ and the wound is protected with special protector. The grasper guides the stomach for this opening. To have better removal it can be firstly pulled the omentum with type alligator grasper, and then pull the stomach and complete extraction of specimen. Please note: greater expansion of the incision may be required for greater tumor.

The device which protects small opening is removed and the abdominal wall is closed in layers in accordance with the preference of the surgeon. The pneumoperitoneum is again reestablished, to perform hemostasis review and cleaning of the cavity. The first drain is positioned through P5 with the help of a grasper in P2 or P3, in the region of the esophagojejunal anastomosis. P2 or P3 keeps the drain in place while the trocar in the portal (P5) is removed (Figure 6).

Since 2009, this procedure has been performed in 164 patients at the Barreto's Cancer Hospital, Barretos, SP, Brazil and this series will be published in near future.

\section{CONCLUSION}

The "reverse anvil" technique used by the authors facilitated the transit reestablishment after total gastrectomy, contributing to obviate reconstruction problems after total gastrectomy.

\section{REFERENCES}

1. Azagra JS, Goergen M, Ansay J, De Simone P, Vanhaverbeek M, Devuyst $L$, et al. Laparoscopic gastric reduction surgery. Preliminary results of a randomized, prospective trial of laparoscopic vs open vertical banded gastroplasty. Surg Endosc. 1999 Jun;13(6):555-8.

2. Azagra JS, Goergen $M$, De Simone $P$, Ibanez-Aguirre J. Minimally invasive surgery for gastric cancer. Surg Endosc. 1999 Apr;13(4):351-7.

3. Azagra JS, Ibanez-Aguirre JF, Goergen M, Ceuterick M, BordasRivas JM, Almendral-Lopez ML, et al. Long-term results of laparoscopic extended surgery in advanced gastric cancer: a series of 101 patients. Hepatogastroenterology. 2006 MarApr;53(68):304-8.

4. Etoh T, Yasuda K, Inomata M, Shiraishi N, Kitano S. Current status of laparoscopic gastrectomy for gastric malignancies. Surg Technol Int. 2010 Oct;20:153-7.

5. Goh P, Tekant Y, Kum CK, Isaac J, Shang NS. Totally intra-abdominal laparoscopic Billroth II gastrectomy. Surg Endosc. 1992 MayJun;6(3):160.

6. Huscher GC, Mingoli A, Sgarzini G, Sansonetti A, Lirici M, Napoletano C, et al. Extended indications of laparoscopic procedures to advanced gastric cancer. Surg Endosc. 2005 May;19(5):737; author reply 8.

7. Ibanez Aguirre FJ, Azagra JS, Erro Azcarate ML, Goergen M, Rico Selas P, Moreno Elola-Olaso A, et al. Laparoscopic ga strectomy for gastric adenocarcinoma. Long-term results. Rev Esp Enferm Dig. 2006 Jul;98(7):491-500.

8. Kim HS, Kim BS, Lee IS, Lee S, Yook JH. Intracorporeal laparoscopic Roux-en-Y gastrojejunostomy after 95\% gastrectomy for early gastric cancer in the upper third of the stomach: a report on 21 cases. J Laparoendosc Adv Surg Tech A. 2013 Mar;23(3):250-7.

9. Kitano $S$, Iso $Y$, Moriyama $M$, Sugimachi K. Laparoscopy-assisted Billroth I gastrectomy. Surg Laparosc Endosc. 1994 Apr;4(2):146-8.

10. Kitano S, Shiraishi N, Uyama I, Sugihara K, Tanigawa N. A multicenter study on oncologic outcome of laparoscopic gastrectomy for early cancer in Japan. Ann Surg. 2007 Jan;245(1):68-72.

11. Kodera Y, Fujiwara M, Ohashi N, Nakayama G, Koike M, Morita S, et al. Laparoscopic surgery for gastric cancer: a collective review with meta-analysis of randomized trials. J Am Coll Surg. 2010 Nov;211(5):677-86.

12. Kojima K, Inokuchi M, Kato K, Motoyama K, Sugihara K. Petersen's hernia after laparoscopic distal gastrectomy with Roux-en-Y reconstruction for gastric cancer. Gastric Cancer. 2013 Apr 5.

13. Marangoni G, Villa F, Shamil E, Botha AJ. OrVil-assisted anastomosis in laparoscopic upper gastrointestinal surgery: friend of the laparoscopic surgeon. Surg Endosc. 2012 Mar;26(3):811-7.

14. Mingoli A, Sgarzini G, Binda B, Brachini G, Belardi V, Huscher CG, et al. Totally laparoscopic approach for treatment of early and advanced gastric cancer. J Am Coll Surg. 2007 Jan;204(1):187-8.

15. Orsenigo E, Di Palo S, Tamburini A, Staudacher C. Laparoscopyassisted gastrectomy versus open gastrectomy for gastric cancer: a monoinstitutional Western center experience. Surg Endosc. 2010 Jan;25(1):140-5.

16. Shim JH, Yoo HM, Oh SI, Nam MJ, Jeon HM, Park $\mathrm{CH}$, et al. Various types of intracorporeal esophagojejunostomy after laparoscopic total gastrectomy for gastric cancer. Gastric Cancer. 2013 Jul;16(3):420-7.

17. Sun J, Li J, Wang J, Pan T, Zhou J, Fu X, et al. Meta-analysis of randomized controlled trials on laparoscopic gastrectomy vs. open gastrectomy for distal gastric cancer. Hepatogastroenterology. 2012 Sep;59(118):1699-705.

18. Vinuela EF, Gonen M, Brennan MF, Coit DG, Strong VE. Laparoscopic versus open distal gastrectomy for gastric cancer: a meta-analysis of randomized controlled trials and high-quality nonrandomized studies. Ann Surg. 2012 Mar;255(3):446-56.

19. Wang DR, Zhao JG, Yu HF, Wang LH, Jiang GQ Li YK, et al. [Laparoscopic versus open surgery for D2 gastrectomy in advanced gastric cancer]. Zhonghua Wei Chang Wai Ke Za Zhi. 2012 Sep;15(9):964-6. 